\title{
Phenology, biomass and associated species of alligator weed at Biratnagar, Nepal
}

\author{
Bhabindra Niroula \\ Department of Botany, P.G. Campus, Tribhuvan University, Biratnagar, Nepal \\ E-mail:niroulab@gmail.com
}

Key words: Associated species, biomass, phenology, productivity

Known as 'Jaljamboo' in Nepal, alligator weed (Alternanthera philoxeroides Griseb,), a native plant of South America (Brazil) is an invasive alien species (IAS) in wetlands in many parts of the tropics and subtropics (Mitsch \& Gosselink, 2000). The weed was first reported from Biratnagar area in 1994 by Siwakoti and Varma. It has invaded wetlands of Nepal's Terai, threatening the existence of native plant species. It thrives well in nutrient rich new habitats in absence of the natural competitors (Tiwari et al., 2005; Siwakoti, 2006; Jha, 2007). This weed is a herb, up to $100 \mathrm{~cm}$ long. Stems simple or branched, solid or fistular, longitudinally striated, with a creeping or floating root base. Leaves are $3-8 \mathrm{~cm}$ long, oblong-obovate, attenuated at base. Flowers are white, bisexual solitary and terminal, bractless peduncled with ovoid or globose shining heads. It propagates vegetatively as well as by seeds.

Realizing its impact on wetland flora and its possible control through biomass utilization (Majid, 1998-99); present work deals with the associated species, phenology and the biomass of the alligator weed in different habitats. Pollution/nutrient loaded water bodies Bhattapokhari, ditch, and Singhia river of Biratrnagar, Nepal were selected for the present study. Biratnagar (Lat. $26^{\circ} 20^{\prime} \mathrm{N} \&$ Long. $87^{\circ} 16^{\prime} \mathrm{E}$, alt. $72 \mathrm{msl}$ ) has alluvial soil, tropical monsoonic climate with three distinct seasons viz., winter (November-February), summer (March-June), and rainy (July-October) in a year (Tab. 1).

The weed was sampled randomly using 10 quadrats of $50 \times 50 \mathrm{~cm}^{2}$ size at monthly intervals from January to December, 2009. Collected samples were washed, brought to the laboratory and oven-dried to constant weight at $80^{\circ} \mathrm{C}$. Productivity was determined as per Trivedy and Goel (1984). Associated species were monitored in the field and identified. Phenology was recorded as per Lodhiyal et al. (1998).

It was a competitor with 12 associated species- free floating (Azolla imbricata (Roxb.) Nakai, Eichhornia crassipes (Mart.) Solms, Lemna minor L., Pistia stratiotes L., Spirodela polyrhiza (L.) Schleid.); and emergent (Ludwigia perennis L., Panicum psilopodium Trin., Paspalidium punctatum (Brum.) A. Camus, Polygonum barbatum (L.) Hara, Ranuculus scleratus L., Sacciolepis interrupta (Willd.) Stapf and Typha angustifolia L.).

The weed underwent perennation during winter and sprouted/germinated from late winter to early summer. Vegetative growth continued up to early rainy season. Flowers were observed from April to August. Fruiting and seed maturation occurred from August to October and the weed underwent senescence in late October (Fig. 1). 
Table 1. Meteorological data of study area (2009).

\begin{tabular}{lcccc}
\hline \multirow{2}{*}{ Months } & \multicolumn{2}{c}{ Temperature $\left({ }^{\circ} \mathrm{C}\right)$} & Rainfall & $\begin{array}{c}\text { Relative } \\
\text { humidity }(\%)\end{array}$ \\
\cline { 2 - 3 } January & Maximum & Minimum & $(\mathrm{mm})$ & humi. \\
February & 23.4 & 11.4 & 0.0 & 98.7 \\
March & 32.5 & 12.0 & 0.0 & 90.8 \\
April & 35.5 & 15.5 & 4.4 & 71.5 \\
May & 33.8 & 22.7 & 17.0 & 68.7 \\
June & 33.7 & 25.2 & 491.3 & 78.3 \\
July & 33.0 & 26.5 & 296.4 & 86.2 \\
August & 32.5 & 26.0 & 455.8 & 87.9 \\
September & 34.2 & 25.0 & 58.0 & 84.5 \\
October & 32.2 & 21.1 & 117.1 & 83.5 \\
November & 29.0 & 15.2 & 0.6 & 84.3 \\
December & 24.5 & 11.3 & 0.0 & 96.4 \\
\hline
\end{tabular}

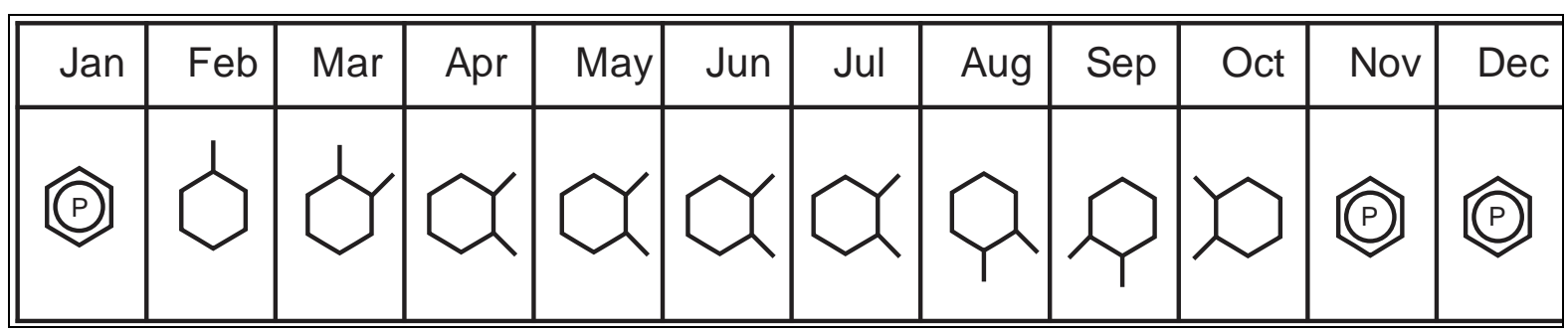<smiles>CC1C(C)C(C)C(C)C(C)C1C</smiles>

1= Germination, $2=$ Vegetative growth, $3=$ Flowering, $4=$ Fruiting, $5=$ Seed maturation, $6=$ Senescence $\& \mathrm{P}=$ Perennation.

Figure 1. Phenological observations on alligator weed.

Table 2. Monthly biomass $\left(\mathrm{g} / \mathrm{m}^{2}\right)($ mean $\pm \mathrm{SE})$ of alligator weed in Bhattapokhari (I), ditch (II), and Singhia river (III).

\begin{tabular}{ccccccccccccc}
\hline Site & Jan & Feb & Mar & Apr & May & Jun & Jul & Aug & Sep & Oct & Nov & Dec \\
\hline I & 0 & 024.2 & 56.0 & 60.6 & 66.6 & 78.6 & 82.0 & 146.6 & 276.0 & 410.8 & 414.6 & 12.0 \\
& & \pm 7.6 & \pm 17.7 & \pm 19.1 & \pm 20.8 & \pm 24.8 & \pm 25.9 & \pm 46.3 & \pm 87.2 & \pm 129.9 & \pm 131.1 & \pm 3.7 \\
\hline II & 144.0 & 187.2 & 376.0 & 1056.0 & 1160.0 & 1188.0 & 2608.0 & 2300.0 & 1072.0 & 336.0 & 144.0 & 88.0 \\
& \pm 45.5 & \pm 59.1 & \pm 118.9 & \pm 333.9 & \pm 366.8 & \pm 375.6 & \pm 824.7 & \pm 727.5 & \pm 338.9 & \pm 106.2 & \pm 45.5 & \pm 27.8 \\
\hline III & 4.6 & 8.4 & 17.0 & 19.0 & 34.6 & 32.4 & 17.1 & 0 & 0 & 0 & 0 & 0 \\
& \pm 1.4 & \pm 3.4 & \pm 5.3 & \pm 6.0 & \pm 10.9 & \pm 10.2 & \pm 5.4 & & & & & 0 \\
\hline
\end{tabular}

Tender shoots of the weed are used as pot herb and fodder during summer. Monthly dry biomass of alligator weed in different water bodies are given in table 2. Favourable months for maximum dry biomass production were as: Bhattapokhari-November, ditch-July and Singhia river-May. Average annual standing crop and productivity was highest in ditch $\left(888.25 \mathrm{~g} / \mathrm{m}^{2}\right.$ and $\left.2520.0 \mathrm{~g} / \mathrm{m}^{2} / \mathrm{yr}\right)$ followed by Bhattapokhari $\left(147.9 \mathrm{~g} / \mathrm{m}^{2}\right.$ and 144.6 
$\left.\mathrm{g} / \mathrm{m}^{2} / \mathrm{yr}\right)$, and least in Singhia river $\left(19.01 \mathrm{~g} / \mathrm{m}^{2}\right.$ and $\left.30.0 \mathrm{~g} / \mathrm{m}^{2} / \mathrm{yr}\right)$, respectively. Differences in the habitats and hydrological regimes of the water bodies might be the possible reasons for disparity in growth and dry matter production. The author is grateful to Dr. S. Jha, Professor and Head, Department of Botany, P.G. Campus, T.U., Biratnagar, Nepal for lab facilities and encouragements. IOST, Dean, T.U., and U.G.C. Nepal are acknowledged for study leave and partial financial support, respectively.

\section{References}

Jha, S. 2007. Phytodiversity of Beeshazar lake and surrounding landscape system. Our Nature 5: 41-51.

Lodhiyal, L.S., S.P. Singh \& N. Lodhiyal. 1998. Phenology, population structure and dynamics of ringal bamboo (Arundinaria falcata) in National hill of Central Himalaya. Tropical Ecology 39(1): 109-115.

Majid, F.Z. 1998-99. Aquatic Weeds Utility and Management. Agro Botanica, Bikaner, India.

Mitsch, W.J. \& J.G. Gosselink. 2000. Wetlands. $3^{\text {rd }}$ edition, John Wiley and Sons, Inc. New York, Chichester, Weinhelm, Brisbane, Singapore, Toronto.

Siwakoti, M. 2006. An overview of floral diversity of wetlands in Terai region of Nepal. Our Nature 4: 83-90.

Tiwari, S., B. Adhikari, M. Siwakoti \& K. Subedi. 2005. An Inventory and Assessment of Invasive alien species of Nepal. IUCN Nepal, Kathmandu.

Trivedy, R.K. \& P.K. Goel. 1984. Chemical and Biological Method for Water Pollution Studies. Environmental Publications, Karad. 